\title{
Nærhet, eller distanse? Lærerstudenters erfaringer med Zoomundervisning under Covid-19
}

Av Ursula Goth, professor NLA Høgskolen og Høyskolen Kristiania, Svitlana Holovchuk, førsteamanuensis NLA Høgskolen, Linnéa K. Jermstad førstelektor NLA Høgskolen og Gunnvi Sæle Jokstad, førstelektor NLA Høgskolen.

\section{Sammendrag}

Våren 2020 vil for mange bli husket som meget utfordrende. Smittevernrestriksjoner i forbindelse med Covid-19 ble innført i hele Norge. Det førte til at høgskolene og universitetene måtte begrense antall mulig tilstedeværende i klasserommet til 20 studenter. Zoom ble derfor innført som digital interaksjonsplattform. Fra mars til feriestart i juli 2020 ble fysisk oppmøte i undervisning unngått. Overgang fra stedsbasert til rent internettbaserte undervisningsplattformer førte til store endringer for både studenter og lærere. Denne studien belyser lærerutdanningsstudenters opplevelse og refleksjoner etter innføringen av Zoom. Studien ser videre på læringsutbytte og endring av motivasjon.

Data som ble inkludert i studien baserer seg på en digital spørreundersøkelse ved oppstarten av 5. semester i grunnskolelærerutdanningen av 50 studenter. Etter intervjuene gjennomførte vi et strukturert litteratursøk. Deretter ble studentenes svar tolket, kategorisert og analysert. Våre resultater viste at motivasjonen hos studenter endret seg over tid ved at den sosiale interaksjonen ble sterkt redusert. Data viste også at studentene opplevde redusert læringsutbytte og frustrasjon. Studien konkluderer med at studentene opplever redusert motivasjon ved rene internettbaserte undervisnings- 
former (Zoom), en reduksjon i motivasjonen som hadde innvirkning på egenopplevd helse og livsmestring.

Nøkkelord: Covid-19, Zoom, lærerstudenter, mestring, læringsutbytte

\section{Abstract}

The spring of 2020 will be remembered by many as challenging. Infection control restrictions in connection with Covid-19 were introduced throughout Norway. As a result, the colleges and universities had to limit the number of attending students in the classroom to maximum 20 persons. Zoom was therefore introduced as a digital interaction platform. From March until the start of the holiday in July 2020, physical attendance at classes was avoided. The transition from location-based to pure Internetbased teaching platforms led to major changes for both students and teachers. This research explores teacher education students' experiences and reflections after the introduction of Zoom. The study looks further at learning outcomes and changing motivation.

Data included in the study are based on a digital survey at the start of the 5 th semester in the primary school teacher education of 50 students. After the interviews, we conducted a structured literature search. The students' answers were interpreted, categorized and analysed. Our results showed that the motivation of students changed over time as the social interaction was greatly limited. Data also showed that students experienced reduced learning outcomes and frustration. The study concludes that students experience reduced motivation through pure internet-based teaching methods (Zoom), a reduction in motivation with impact on self-perceived health and life skills.

Keywords: Covid-19, Zoom, teacher students, mastery, learning outcomes 


\section{Innledning}

I mars 2020 opplevde befolkningen i Norge en dramatisk endring på grunn av Covid-19 (FHI.no, 2020). Den 12. mars 2020 kom regjeringen med de mest inngripende tiltak Norge har sett siden 2. verdenskrig, blant annet stengning av alle barnehager, skoler, høgskoler og universiteter i Norge. Undervisningstilbudet kunne ikke formidles lenger gjennom forelesninger, og Zoom som digital undervisningsplattform, ble innført «over natten». Verken studenter eller undervisningspersonalet var forberedt. Dette hadde sin innvirkning på utdanningskvaliteten. Digital undervisning har i stigende grad påkalt interesse og vekket debatt (Aagaard, Lund, Lanested, Ramberg \& Swanberg, 2018). Digital undervisning og studenter påvirker hverandre gjensidig, og dette har effekt på studenters læringsutbytte (Fuglseth, 2020; Magerøy, 2019).

Etter vårens omstilling til full digitalisert undervisning er det viktig å se på hvordan dette har vært for studenter. I den amerikanske nyhetsavisen The Guardian kan vi lese at studenter mangler en funksjonell fysisk plass for hjemmestudier, «det demotiverer dem, de føler ikke at de klarer å stå opp for å studere» (Hall \& Batty, 4 May, 2020 [vår oversettelse]). Videre har flere forskere sett nærmere på studentenes totale opplevelse (Fuglseth, 2020). I en amerikansk studie som inkluderte 45000 studenter ser man en signifikant $ø$ kning av psykiske problemer blant studenter under pandemien (Chirikov, Soria, Horgos \& Jones-White, 2020). Forskerne begrunner dette med at måneder med fjernundervisning, hjemmekontor, sosial isolasjon og usikkerhet om fremtiden, påvirker studentene (Svarstad, 2020). Men hvordan opplever studenter i Norge situasjonen? Som det fremgår av litteratursøket har vi kun begrenset informasjon om studentenes erfaringer fra en norsk kontekst. I en mindre studie som ble offentliggjort to måneder etter Covid19-sanksjonene, rapporterte sju av ti studenter at de gjorde en dårligere innsats under korona. For å kunne øke studentenes læringsutbytte ble det konkludert med at «studentene må tilbake på campus i størst mulig grad», og så snart som mulig (Hanger, 2020).

Campusundervisning muliggjør sosial interaksjon mellom studenter, og mellom studenter og lærer. Å møtes ansikt til ansikt kan ha en sosial og motiverende funksjon, og slike situasjoner kan gi energi og entusiasme som er 
både spontan og smittsom (Bingen \& Aasbrenn, 2012). Dette er sentrale elementer knyttet til sosiokulturell læringsteori der vi vektlegger samspill og kommunikasjon med andre som et medierende redskap for egen læring og utvikling (Vygotsky, 1978). Vi møter ikke verden direkte, men gjennom medierende psykologiske og fysiske redskaper ifølge (Vygotsky, 1978). De ulike artefaktene vi har til rådighet, vil da være av avgjørende betydning. Vygotsky har et dialektisk perspektiv i form av en gjensidig påvirkning mellom menneske og miljø. Grupper av mennesker påvirkes av det miljøet de lever i og enkeltmennesket formes gjennom å bli gjort delaktig i kulturens språk, kunnskaper og redskaper. Men mennesket er ikke bare et objekt, men har ifølge Vygotsky også muligheten til å påvirke, til å være et subjekt (Halvorsen, 2017, s. 201). Kunnskapen trer tydelig fram i dialogen og den lærende må selv være aktivt med i prosessen, slik at begreper blir tydeligere og personlig formulerte. Dette er viktig for det neste trinnet i utviklingen, det Vygotsky kaller den narmeste utviklingssonen; å gå fra det lærerstyrte til det selvstendige arbeidet (Kroksmark, 2006, s. 333). Dette er også i tråd med Lave og Wengers Lave og Wengers (1991) læringsteori som nedtoner det kognitive aspektet ved læring til fordel for deltakelse i praksisfellesskapet. Fokuset er da skiftet fra kunnskap som noe gitt som kan overføres, til noe vi deltar i og kommuniserer om.

Overgangen fra deltakelse i praksisfellesskapet til digital undervisning gjennom den digitale plattformen Zoom, ble også en realitet for studenter ved grunnskolelærerutdanningen (GLU) ved NLA høgskolen. Et halvt år senere, i september 2020, konfronterer medier oss med rapporter som omtaler studenters egenopplevelser. Et hovedoppslag på norsk TV avdekket at «tre av fire synes utdanningen som er Zoombasert har blitt dårligere» (TV2, 4. sept 2020) og dette medførte at offentlige organer forsterket sitt fokus på frafall (Aftenposten, 2020, 12. sept.; Braathen, 2020, 10. sept.).

Lærerstudentene har et profesjonelt pedagogisk syn og er dermed bevisste på læring, mestring og pedagogiske tilnærminger. Det er derfor spesielt interessant å undersøke GLU-studentenes pedagogiske refleksjoner over egen læring og deres opplevelse av mestring gjennom de første 5 mnd. etter innføring av Covid-19-restriksjoner. Problemstillingen ble dermed: Hvilke opplevelser har GLU-studentene med zoomundervisning de forste 5 mnd. etter innføring under Covid-19? 


\section{Metode}

Artikkelen baserer seg på funn som fremkom i en digital spørreundersøkelse med 50 GLU-studenter ved NLA og gjennom et strukturert litteratursøk.

Spørreundersøkelsen: Spørreundersøkelsen ble gjennomført elektronisk basert på «Nettskjema», en digital løsning for datainnsamling på nett som er administrert av Universitetet i Oslo. Undersøkelsen ble gjennomført 6 måneder etter Covid-19-utbrudd og overgang til digital undervisning. De 50 informantene er lærerstudenter på 3. året i sin 5-årige masterutdannelse. Herav var 44 studenter mellom 20 og 29, to studenter mellom 30 og 39 og en student mellom 40 og 49.

Den anonyme spørreundersøkelsen ble kunngjort i undervisningstimen. I undervisningen ble studentene informert om studiet, og at det var frivillig å delta og/eller å reservere seg. $61 \%$ av de forespurte studentene (n: 50 studenter), ble inkludert i studien. De fleste spørsmålene, syv spørsmål, var kvalitative, mens to spørsmål var kvantifiserbare (se vedlegg). Dette gav oss mulighet til å innhente både beskrivelser som uttrykk for en personlig opplevelse, og også kvantifiserbare og beskrivende faktorer knyttet til hele kullet. En slik blanding medfører en større kontekstforståelse og derved en bedre fortolkningsramme for de innhentede data.

Etter den digitale spørreundersøkelsen gjennomførte forfatterne et strukturert litteratursøk i databasene Idunn, Oria, Google Scholar og Eric. Søket ble begrenset til 2020 med søkeordene: Covid-19, Zoom, student, mestring, laringsutbytte, med utvidelser på nettbasert undervisning, digital teknologi, digital kompetanse, sosialt nettverk, mental helse og motivasjon. Inklusjonskriterier var norsk, svensk, dansk, tysk og engelsk. Femten fag- og vitenskapelige artikler ble inkludert i studien.

Analyse: Funn fra litteratursøket og den digitale undersøkelsen ble analysert basert på en fenomenologisk analyse (Rendtorff, 2007, s. 277-307) for å kunne belyse fenomenenes meningsinnhold slik de viser seg i den konkret erfarte virkelighet i praksis (Fuglesang \& Bitsch Olsen, 2007, s. 570).

Dialogen mellom studentens stemmer og faglitteraturen er en konstruksjon og derfor åpen for tolkning. Derfor ble studentenes svar analysert, kategorisert og drøftet mot de ulike forsknings- og fagartiklene som ble fremskaffet gjennom det strukturerte litteratursøket. En slik metodetriangulering 
vil styrke funnenes pålitelighet og gyldighet (Postholm \& Jacobsen, 2018, s. 236).

Etikk: $\AA$ anvende studentenes beretninger som uttrykk for studentenes personlige meningsskaping, fordrer ærbødighet og respekt. En slik forskningsetisk holdning har vi vært bevisst på under analysen.

Om studentene oppfattet spørsmålene slik de var tenkt og svarte ærlig, er et uttrykk for studiens reliabilitet og validitet (Postholm \& Jacobsen, 2020, s. 222-224). Dette er alltid et usikkerhetsmoment, og konklusjoner må trekkes med varsomhet. Likeledes må vi alltid spørre oss selv om vår påvirkning som forskere, og om noen spørsmål kunne bli oppfattet som ledende. Dette er usikkerhetsmomenter da utforming av spørsmål kan måtte anses som en egen vitenskap (s. 225). Alle disse hensynene er forsøkt ivaretatt gjennom hele forskningsprosessen og herved løftet fram og gjort rede for.

For å ivareta studentenes (informantenes) anonymitet gjennom hele prosessen ble undersøkelsen gjennomført slik at identiteten til den enkelte ikke kan gjenskapes. Sitatene ble derfor identifisert gjennom informantenes løpenummer fra nr. $1-$ nr. 50 .

\section{Funn og diskusjon}

Analysen som inkluderte både spørreundersøkelsen og litteratursøket viste følgende kategorier: Digital undervisning \& digital kompetanse, Laringsutbytte, Sosial interaksjon og Motivasjon.

\section{Digital undervisning og digital kompetanse}

Teknologi har stor betydning for lærerutdanningen. Teknologi benyttes som støtte i digital undervisning og kan gi studentene et bedre læringsutbytte (Romstad, 2018). Studentene kan studere når og hvor de vil, og slik utvikle nye ferdigheter i prosessen som fører til livslang læring (Dhawan, 2020, p. 6). Men digitalisering i den høyere utdanningen krever en økning av digital kompetanse og ferdigheter «for å undervise studenter på gode måter i en digital kontekst» (Hjukse, Aagaard, Bueie, Moser \& Vika, 2020, s. 27). Slik transformasjon av praksiser, forstått som undervisning og læring, har høy 
relevans for brukerne, og det rokker både ved læringsprosesser og hva vi legger i læringsutbytte (Aagard et. al., 2018).

Digital undervisning er både avhengig av digital kompetanse, men også av medierende redskaper (Vygotsky, 1978), der digitale verktøy kan være en slik artefakt. Det digitale verktøyet består av ulike elementer som video, lenker som inviterer til fordypning, samskriving på whiteboard samt spontanchat mellom lærer og student. Alle disse ulike elementene kan oppleves som både slitsomme og utfordrende. Vi så at flere studenter ønsket mer interaksjon med lærerne enn opptak av forelesningene (student 4, 33, 48 og 49), men som student 33 påpekte, så hadde ikke alle foreleserne kompetanse til å gjøre det. Lærerens digitale kompetanse har altså betydning for studentenes læringsutbytte. Forskning viser at utviklingen av lærerstudenters profesjonsfaglige digitale kompetanse (PfDK) i svak grad har vært arbeidet med i norsk grunnskolelærerutdanning (Hjuske et al., 2020). For å øke den digitale kompetansen, eller den "profesjonsfaglige digitale kompetansen", er det utarbeidet et nasjonalt retningsgivende dokument, kalt «Rammeverk for lærerens profesjonsfaglige digitale kompetanse (PfDK)». Rammeverket er et dokument som "politikkutviklere, instituttledere, lærerutdannere, lærere, lærerstudenter og andre kan bruke som referanse i arbeidet med å øke kvaliteten i lærerutdanning og systematisk etter- og videreutdanning av lærere» (Utdanningsdirektoratet, 2018, 5. febr.).

Ofte argumenterer man med at hjemmesituasjonen tilspisset seg når skolene og barnehagene stengte og barn var hjemme mens foreldre måtte fortsette med jobb eller skolegang. Det viste seg at 86 prosent av GLU-studentene ikke hadde forsørgeransvar. Vår studie viste også at studentene fra alle aldersgrupper hadde tilstrekkelig IT-kompetanse og nødvendig utstyr på hjemmekontoret. Utfordringen GLU-studentene opplevde var ikke knyttet til mangel på digital kompetanse eller mangel på digitalt utstyr hjemme. Allikevel ble overgangen til Zoom-undervisning en utfordring. En undersøkelse ved Universitetet i Oslo som ble gjennomført etter en uke med digital undervisning viste at studentene opplevde undervisningstilbudet tilfredsstillende, men påpekte et stort forbedringspotensial (Langford, Damsa, Larsen, Slåttå, Westbye \& Wulff, 2020). Da digital kompetanse ikke ble tolket som en utfordring, så vi nærmere på sammenhengen mellom utdanningskvalitet og digitalisering og en ny kobling mellom undervisning og læring. Her viser 
Aagard et al. at digitale verktøy kan invitere til en annerledes studentaktivitet, til samarbeidslæring og til multimodale uttrykksmåter (Aagaard, et al., 2018, s. 291). Med innføring av Zoom ble konteksten for læring og utdanning ikke lenger begrenset til det ordinære klasserommet. Det fordrer at synet på læring og undervisning må endres (Ferdig, Baumgartner, Hartshorne, Kaplan-Rakowski \& Mouza, 2020; Johanson \& Karlsen, 2018, s. 13). I en slik kontekst viser sosiokulturell læringsteori at studenter og lærere er avhengig av kommunikasjon og samarbeid, i en direkte interaksjon med andre for å lære. Her mener Vygotsky at vi ikke møter verden direkte, men gjennom medierende psykologiske og fysiske redskaper (Vygotsky, 1978). Disse psykologiske og fysiske redskapene vil ha en avgjørende betydning. Digitale verktøy er kulturelle redskaper som forandrer måten vi tenker og samhandler på som gir rom for transformative og kreative prosesser. Hvorvidt læring og utvikling skjer, er avhengig av at man klarer å nyttiggjøre seg av de kulturelle redskaper en har til rådighet (Mikkelsen \& Rist, 2018, s. 166). For at utvikling kan finne sted må deltakere være aktive i læringsprosessene. Dersom studentene forblir passive, vil ansvarstaking hemmes og fremmedgjøringen øker (Skjervheim, 1996). Lignende resultater finner vi også i Lave og Wengers læringsteori som nedtoner det kognitive aspektet ved læring til fordel for deltakelse i praksisfellesskapet (Lave \& Wenger, 1991). Fokuset vil da ha skiftet fra kunnskap som noe gitt som kan overføres, til noe vi deltar i og kommuniserer om.

\section{Laringsutbytte}

Kvaliteten i den høyere utdanningen avhenger av læringsutbyttet og knyttes til begrepene "kompetanse, kvalifikasjon og ferdigheter", som kan utvikles i studier på tvers av disipliner (Aamodt, Prøitz, Hovdhaugen \& Stensaker, 2007, s. 12). Men kompetanse, kvalifikasjon og ferdigheter som omfavnes av læringsutbytte, er også avhengig av kulturens sosiale institusjoner (Manger, 2012, s. 22). I sosiokulturell teori oppfattes læring som aktiv problemløsning i samhandling med andre mennesker (Manger, 2012, s. 29). Våre individuelle kompetanser strammer fra ulike former for interaksjon med hverandre. I vår studie var det 86 prosent av studentene som opplevde mindre faglig utbytte etter innføring av Zoom. Dette kommer også fram i studentenes mange 
kommentarer. «Vanskeligere å konsentrere seg, vanskeligere å jobbe i grupper på zoom og vanskeligere å forstå stoffet» (student 33). En annen student beskrev det slik: «Det er mye mer utfordrende å holde fokus i undervisningen. Man mister lett fokus, og jeg føler jeg lærer mindre enn jeg gjør i campusundervisning. Jeg føler jeg i mye større grad må lære meg alt stoffet selv» (student 28). Dette begrunner student $36 \mathrm{med}$ at undervisningssettingen var vanskelig da «flere forelesere ikke helt hadde forstått seg på zoom som førte til mye nøling og diskusjoner mellom foreleserne i løpet av undervisningen». Det førte til at undervisningen ble mindre variert, vanskeligere å følge med (student 35) og studenter karakteriserte undervisning som utfordrende med dårligere kvalitet på en del undervisning (student 16). Også utvidet skjermtid hver dag i seg selv ble opplevd som slitsomt, og 15 av 50 studenter rapporterer om manglende konsentrasjon, eller at det er vanskelig å følge med på nettundervisningen. Opplevelsen av manglende konsentrasjon førte til redusert læringsutbytte i forelesningene. I motsetning til funn etter en ukes digital undervisning ved $\mathrm{UiO}$ (Langford et al. 2020, s. 23; Ferdig et al., 2020), viser våre funn, 6 måneder senere, at studentene opplever et markant dårligere læringsutbytte. Dette kan trolig skyldes tidsaspektet de ulike undersøkelsene ble gjennomført på, og at studenter opplever et forsterket stress over en slik undervisningsform over lengre tid og knyttet til vurdering.

Enkelte studenter påpekte at undervisningen faktisk ble bedre etter noen uker, men det var kun to studenter som opplevde at internettbasert undervisning gav dem et større læringsutbytte enn stedsbundet undervisning og kommenterte at lærerne hadde lært å bruke verktøyet bedre.

Under Covid-19 ble utdanningsinstitusjoner pålagt å gjennomføre svært raske endringer gjennom introduksjonen av Zoom. Dermed ble digital undervisning og selvstudier det alternativet studentene måtte benytte seg av for å fullføre de ulike læringsoppgavene. I begynnelsen av nedstengningen påtok de seg derfor ofte rollen som innholdsleverandører (Yao, Rao, Jiang, Xiong, 2020, p. 519). Det man så etterhvert, var at konsentrasjonen kunne løftes gjennom å jobbe i grupper (Breakout Rooms) og via samtale (chat) som supplement til opptak. 


\section{Sosial interaksjon}

Sosial interaksjon, eller samhandling, betegner samspill eller vekselvirkning mellom to eller flere personer som er i aktivitet med hverandre i ulike settinger. En av disse settingene er undervisning hvor samhandlingen er knyttet til en eller annen form for direkte kommunikasjon. Undervisning har lenge vært preget av sosial interaksjon med fysisk tilstedeværelse, til tross for at den digitale utviklingen har ført til økt bruk av nettbasert læring. Vi ser at den digitale utviklingen og den nettbaserte undervisningen gir unike muligheter til læring, samtidig som den gir utilsiktede konsekvenser (Jensen, 2018, s. 206). Covid-19 kan ha endret utdanningen for alltid, men når mennesker forsvinner i det digitale, kan tilværelsen bli fragmentert (Vidnes, 2020). Opplevelsen av en slik fragmentert tilværelse med mangel på sosial interaksjon både privat og i en arbeids- eller skolekontekst, ble påpekt som et viktig element av de fleste studenter i vår studie. Student nr. 43 beskrev denne opplevelsen som følgende: «Dårligere kontakt, læreren kunne like godt snakket til en vegg. Det er vanskeligere å følge med, og det er trist å skulle sitte $\mathrm{i}$ samme rom i mange timer alene (student 43).»

De fleste andre studenter som inngikk $\mathrm{i}$ vår studie, problematiserte ensomheten og beskrev det som én som sitter alene «der ute» uten å være $\mathrm{i}$ fysisk kontakt med andre. Det ble beskrevet som: «Ensomt. Mangel på følelsen av tilhørighet», student 13. En tredje student skrev: «Treffer ikke andre medstudenter og lite interaksjon med lærer. Vanskeligere å stille spørsmål når det er zoomundervisning (student 10)» mens student 38, «Synes det har vært kjipt å gå over til digital undervisning, mest fordi vi har mistet mye av det sosiale vi opplever på studiestedet.» Men dette gjelder ikke bare studenter. I løpet av koronakrisen har også store deler av befolkningen opplevd stress, angst og depresjon (Pragholapati, 2020. p. 4). Når utdanningsinstitusjoner avlyste fysisk undervisning på campus og byttet til nettbasert undervisning på Zoom samtidig som landet stengte ned, endret studentenes liv seg over natten (StudentTorget.no., 2020). Det viste seg at reduserte sosiale interaksjoner, mangel på sosial støtte og nylig oppståtte stressfaktorer, hadde negativt utslag på studentenes psykiske helse (Elmer, Mepham \& Stadtfeld, 2020, p. 1-2). I løpet av de siste 6 måneder har det blitt publisert flere undersøkelser knyttet til dette temaet (Elmer et al., 2020; Sahu, 2020). Derfor mener vi at det finnes grunn til å tro at utbruddet også for våre studenter førte til 
et bredt spekter av psykiske og psykologiske utfordringer som angst, frykt, posttraumatisk stress, depresjon, tap av plan for fremtiden, som å være bekymret for å ikke klare å gjennomføre studiene (Berggren \& Næsje, 2020).

Våre funn viser at når pandemien krever drastiske grep som omlegging fra synkron til asynkron undervisning, oppleves undervisningen som et dårligere tilbud og den menneskelige kontakten savnes. Derfor må man ta høyde for opplevelsen og gi studentene støtte for å klare utfordringene de har fått. Det kan være både studieveiledning, psykologisk rådgivning, eller rett og slett et fysisk møte dersom det er gjennomførbart. Det har også vist seg at noen studenter har en høyere risiko for sosial isolasjon og utvikling av psykiske helseproblemer under slike forhold. Når studentene bor for seg selv, har mindre direkte kontakt med nære familiemedlemmer og venner, opplever den enkelte mangel på sosial støtte. Fra tidligere vet vi at studentene, spesielt studenter som nettopp har flyttet hjemmefra, har en svakere integrering i sitt naturlige sosiale nettverk (Elmer et al., 2020, p. 19; Ferdig et al., 2020). Studenter som er svakt integrert, er derfor spesielt utsatt for psykiske reaksjoner ved opplevelsen av isolasjon under nedstengning. Et annen moment er bekymring for egen helse og for helsen til familiemedlemmer (Son, Hegde, Smith, Wang \& Sasangoha 2020).

\section{Motivasjon}

Motivasjon kan defineres som «en tilstand som forårsakes hos individet, styrer aktiviteten i bestemte retninger og holder den ved like» (Manger, 2012, s. 14), og det skilles mellom ytre og indre motivasjon. Vi vet at motivasjon er relasjonelt betinget - både for oss og mellom oss. Sett fra et sosiokulturelt synspunkt legger menneskelig motivasjon hovedvekten på den sosiale samhandlingen eller sosiale interaksjonen som individet er en del av (Manger, 2012, s. 15).

Motivasjon har vært et gjennomgående tema for våre informanter. Basert på den kvantitative delen i vår studie ser vi at 68 prosent av studentene opplever seg mindre eller mye mindre motivert for studiet siden innføring av Zoom, mens seks prosent svarer at motivasjonen har økt. Dette begrunnes med at det er vanskeligere å holde fokus på undervisning når den er på nett. Student 24 beskrev sin opplevelse slik: 
«Jeg synes det er vanskeligere å henge med i fagene over nett, noe som igjen gjør at jeg blir mer demotivert om jeg først faller av», mens student 22 opplevde seg «Mindre motivert fordi det kan være ting som kommer i veien for foreleser på zoom».

Her peker studentene både på egen evne til konsentrasjon og på forelesers digitale kompetanse. Årsakene som ble nevnt av de fleste studenter, er allikevel mangel på den sosiale interaksjonen, tilstedeværelsen av medstudenter og de trygge rammer studiehverdagen medfører. Et beskrivende utsagn kom fra student 2 som sa at hun ble «mindre motivert da jeg liker å ha studievenner rundt meg slik at vi kan samarbeide». Samarbeid og fysisk nærhet ble beskrevet som avgjørende for sin motivasjon. Lignende funn finner vi i en studie av Jeno hvor han konkluderer med at isolasjon og ensomhet kan ha en negativ effekt, og at motivasjon skaper interesse, engasjement og glede (Jeno, 2017; Jeno, 2020).

Innføring av digital undervisning som formidling skjedde ved NLA i løpet av 48 timer. Flere studenter beskrev denne overgangen til Zoom som altfor brå og drastisk. Den raske overgangen førte til at studentene ble mindre motivert samtidig som de opplevde at institusjonen presset for hardt. Student 39 beskrev det som å 'passe på at alle studentene fulgte den samme progresjonen.

Informasjonsmassen ble opplevd som overveldende, og sammen med en endret hverdag medførte det redusert motivasjon. Student 41 beskrev situasjonen som at «Det er vanskeligere å samarbeide over nett, få med seg alle møter og frister, i tillegg til at når læringsutbytte er redusert i undervisningen, så føles arbeidet så mye mer besværlig og krevende». Zoom anses kun å være "ok som en backup eller kortvarig erstatning, men at det skulle bli den nye hverdagen i så lang tid fremover som det har vært (og vil bli) er ikke ideelt hverken faglig eller sosialt» (student 29).

\section{Konklusjon}

Studentene opplevde den plutselige overgangen fra synkron til asynkron undervisning med Zoom ved nedstengning under Covid-19 pandemien, som utfordrende. Det var spesielt mangelen på sosial interaksjon som 
påvirket både læringsutbytte, elevenes psykiske helse og deres motivasjon. Dette samsvarer med sentrale elementer i Vygotskys sosiokulturelle læringsteori der samspill og kommunikasjon med andre anses som et medierende redskap for egen læring og utvikling. Digitale verktøy, slik som Zoom, er et medierende redskap, men det er likevel ikke et likeverdig alternativ til fysisk undervisning fordi den sosiale interaksjonen delvis eller helt uteblir. Digital undervisning fordrer derfor at lærerne innehar digital profesjonsfaglig kompetanse og kan tilrettelegge for sosial nettbasert interaksjon mellom studentene og mellom lærer og student slik at studentene opplever undervisningen som meningsfull. Planlegging av et digitalisert undervisningstilbud må derfor tilrettelegges i samarbeid med studentene om de skal klare å opprettholde den motivasjonen som kreves for å være aktiv lærende.

\section{Referanser}

Aftenposten (2020, 12. sept.). UiO-rektor advarer mot digitale studier. Hentet fra https://www.aftenposten.no/norge/politikk/i/X8wbOm/uiorektor-advarer-mot-digitale-studier

Aagaard, T., Lund, A., Lanestedt, J., Ramberg K. \& Swanberg, A.B. (2018). Sammenhenger mellom digitalisering og utdanningskvalitet - innspill og utspill. Uniped 41(3-20) 289-303. DOI: 10.18261/ISSN.18938981-2018-03-09

Aamodt, P.O, Prøitz, T.S., Hovdhaugen, E. \& Stensaker, B. (2007). Læringsutbytte i høyere utdanning. En drøfting av definisjoner, utviklingstrekk og måleproblemer [Rapport]. NIFU STEP Studier av innovasjon, forskning og utdanning.

Berggren, S. \& Næsje, R.L. (2020). Studentene våre vil vare på campus - ikke i skyen! Forskersonen.no. Hentet fra https://forskersonen.no/kronikkmeninger-skole-og-utdanning/studentene-vare-vil-vaere-pa-campusikke-i-skyen/1681613

Bingen, H.M. \& Aasbrenn, M. (2012). Fleksibel fagdiskusjon. Uniped 03(35)16-31. Hentet fra https://www.idunn.no/uniped/2012/03/fleksibel_fagdiskusjon 
Braathen, F. (2020, 10.sept). Kunnskapsministeren er bekymret for at koronafravær kan føre. Til at færre gjennomfører skolen. Aftenposten. Hentet fra https://www.aftenposten.no/norge/i/9Omm2w/kunnskapsministeren-er-bekymret-for-at-koronafravaer-kan-foere-til-at-fae

Chirikov, I., Soria, K.M., Horgos, B. \& Jones-White, D. (2020). Undergraduate and Graduate Students'Mental Health During the COVID-19 Pandemic . UC Berkeley: Center for Studies in Higher Education. Hentet fra: https://escholarship.org/uc/item/80k5d5hw

Dhawan, S. (2020). Online Learning: A Panacea in the Time of COVID19 Crisis. Journal of Educational Technology Systems 49(1) 5-22. https://doi.org/10.1177/0047239520934018

Elmer T., Mepham K., Stadtfeld, C. (2020). Students under lockdown: Comparisons of students' social networks and mental health before and during the COVID-19 crisis in Switzerland. PLoS ONE 15(7): e0236337.

https://doi.org/10.1371/journal.pone.0236337

Ferdig, R.E., Baumgartner, E., Hartshorne, R., Kaplan-Rakowski, R. \& Mouza, C. (red.) (2020). Teaching, Technology, and Teacher Education During the COVID-19 Pandemic: Stories from the Field. Association for the Advancement of Computing in Education (AACE). Hentet fra https://www.learntechlib.org/p/216903/

FHI.no (2020). Coronavirus. Hentet fra https://www.fhi.no/nettpub/coronavirus/

Fuglesang, L. \& Bitsch Olsen, P. (red.). (2007). Videnskapsteori i samfunnsvidenskaperne: På tvers av fagkulturer og paradigmer $i$ samfundsvidenskaperne. Roskilde: Roskilde Universitetsforlag.

Fuglseth, K.S. (2020). Digital danning med m-læring?: Danningsdidaktiske perspektiv på læring med digitale ressursar. Prismet 71(1) 45-58. doi: 10.5617/pri.7873

Hall, R., Batty, D. (4 May 2020). 'I can't get motivated': the students struggling with online learning. The Guardian. Hentet fra https://www.theguardian.com/education/2020/may/04/i-cant-get-motivated-thestudents-struggling-with-online-learning

Halvorsen, T. (2017). Pedagogikkens pioner. Oslo: Gyldendal akademisk.

Hanger, M.R. (2020, 13. mai). Sju av ti studenter gjør en dårligere innsats under korona. Universitetsavisa UA. Hentet fra 
https://www.universitetsavisa.no/koronavirus/2020/05/13/Sju-av-ti-studenter-gjør-en-dårligere-innsats-under-korona-21808772.ece

Hjukse, H., Aagaard, T., Bueie, A.A., Moser, T. \& Vika, K.S. (2020). Digitalisering i grunnskolelærerutdanningen: Om faglige forskjeller i arbeidet med profesjonsfaglig digital kompetanse. Acta Didactica Norden, 14(1)27 sider. https://doi.org/10.5617/adno.8023

Jeno, L.M. (2017). Hvordan teknologi bidrar til biologistudenters motivasjon og læring. [konferansebidrag]. MNT-konferansen 2017, 30.-31. mars, Oslo. Hentet fra https://bioceed.uib.no/dropfolder/bioCEED/ MNT2017-Jeno.pdf

Jeno, L.M. (2020, 26. aug). Motivasjonstips for studenter som studerer hjemmefra. Hentet fra https:/www.uib.no/korona/135605/motivasjonstipsstudenter-som-studerer-hjemmefra

Jensen, I. (2018). «Det er jo ikke skadelig å være foran en skjerm - man blir jo ikke syk av det». I L. B. Johanson \& S. S. Karlsen (red.) I: Restart: $\AA$ vare digital i skole og utdanning. (s. 197-207). Oslo: Universitetsforlaget. Johanson, L.B. \& Karlsen, S.S. (red.). (2018). I: Restart: Å vare digital i skole og utdanning. Oslo: Universitetsforlaget.

Kroksmark, T. (2006). Den tidløse pedagogikken. (Overs. Ane Sjøbu). Bergen: Fagbokforlaget.

Langford, M., Damsa, C., Larsen, J.M.R., Slåttå, K.S., Westbye, H. \& Wullff, S.S.T. (2020). Første uken med digital undervisning i koronatiden: Jusstudentenes erfaring. [Rapport]. Hentet fra https://www.jus.uio.no/ cell/digitaldugnad/rapporten-om-jusstudenters-evaluering-av-digitalundervisning-29-mars-2020.pdf

Lave, J. \& Wenger, E. (1991). Situated Learning: Legitimate Peripheral Participation. Cambrigde: Cambrigde University Press.

Magerøy, N.M. (2019). Digital kompetanse i høyere utdanning: Erfaringer med bruk av undervisningsvideo og omsnudd undervisning ("flipped classroom») $i$ samfunnsfag $i$ barne- og grunnskole-larerutdanninga. [Notat nr. 7]. Høgskulen i Volda. Hentet fra https://bravo.hivolda.no/hivoldaxmlui/handle/11250/2633961

Manger, T. (2012). Motivasjon og mestring. Oslo: Gyldendal akademisk. 
Mikkelsen, R. \& Rist, M. (2018). Lærerstudenters digitale praksismøter. I: L.B. Johanson, \& S.S. Karlsen (red.) Restart: Å vare digital i skole og utdanning. (s. 163-177). Oslo: Universitetsforlaget.

Postholm, M.B. \& Jacobsen, D.I. (2018). Forskningsmetode for masterstudenter $\mathrm{i}$ larerutdanning. Oslo: Cappelen Damm akademisk.

Pragholapati, A. (2020). Covid-19 impact on students. Publisher: Frontiers Media SA. DOI. 10.35542/osf.io/895ed

Rendtorff, J.D. (2007). Fænomenologien og dens betydning. I: L. Fuglesang, \& P. Bitsch Olsen, (red.). (2007). Videnskapsteori i samfunnsvidenskaperne: På tvers av fagkulturer og paradigmer $i$ samfundsvidenskaperne. (s.277-307). Roskilde: Roskilde Universitetsforlag.

Sahu, P. (April 04, 2020). Closure of Universities Due to Coronavirus Disease 2019 (COVID-19): Impact on Education and Mental Health of Students and Academic Staff. Cureus 12(4): e7541. Doi: 10.7759/cureus.7541

Skjervheim, H. (1996). Deltakar og tilskodar og andre essays. Oslo: Aschehoug $\&$ Co.

Son, C., Hegde, S., Smith, A., Wang, X., Sasangohar, F. (2020). Effects of COVID-19 on College Students' Mental Health in the United States: Interview Survey Study. Doi: 10.2196/21279

Student Torget.no (2020, 12. mars). Koronaviruset - dette gjør universitetene. Hentet fra https://studenttorget.no/index.php?show=4940\&expand= 3797,4940\&artikkel id=20174

Svarstad, J. (2020, 26. august). Stor økning i psykiske problemer blant studenter under pandemien, ifølge amerikansk undersøkelse. Forskerforum. Hentet fra https://www.forskerforum.no/stor-okning-i-psykiske-problemer-blant-studenter-under-pandemien-ifolge-amerikansk-studie

TV2 Nyhetskanalen (2020, 4. september). Intervju [nyhetsinnslag]. Hentet fra https://twitter.com/NOKUT_No/status/1301831687253487617?s=20 Utdanningsdirektoratet (2018, 5. febr). Rammeverk for larerens profesjonsfaglige digitale kompetanse (PfDK). Hentet fra https://www.udir.no/kvalitetog-kompetanse/profesjonsfaglig-digital-kompetanse/rammeverk-larerens-profesjonsfaglige-digitale-komp/

Vidnes, A.K. (2020). Korona har trolig endret høyere utdanning for alltid. Men hva mister vi med den digitale revolusjonen? Forskerforum. Hentet fra https://www.forskerforum.no/hva-har-vi-laert/ 
Yao, J., Rao, J., Jiang, T., Xiong, C. (2020). What Role Should Teachers Play in Online Teaching during the COVID-19 Pandemic? Evidence from China. Doi: 10.15354/sief.20.ar035

Vygotsky, L.S. (1978). Mind in Society. The Development of Higher Psychological Processes. Cambridge: Harvard University Press. 


\section{Forskningsprosjekt "Undervisning og Læring gjennom Zoom"}

Covid 19 situasjonen ser ut til å fortsette i månedene som kommer og nettundervisning vil derfor stå sentralt. Vi er fire lærere på pedagogikkseksjonen som ønsker å tilrettelegge zoomundervisningen på best mulig måte og trenger deres innspill. Vi setter stor pris på om du fyller ut dette skjemaet.

Den 12.mars i år da NLA Høgskolen som andre høgskoler ble nedstengt endret mye seg for studenter og ansatte. Vi ønsker å vite hvordan du opplevde situasjonen.

Informasjonen er sendt ut via Nettskjema.no som anonymiserer din identitet. Det er frivillig å delta i undersøkelsen, men det er viktig for både høgskolen og for dere studenter at så mange som mulig deltar slik at vi bedre kan legge til rette for optimal undervisning i fremtiden.

Alder

Du må velge minst ett svaralternativ.

\section{9-30}

$31-40$

$41-50$

$\Gamma$

$51-60+$

Hvordan opplevde du overgangen fra campusundervisning til zoomundervisning? Nevn 3-5 momenter.

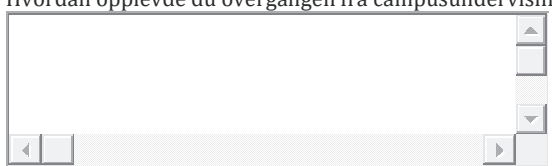

Hvordan påvirket omlegging til zoomundervisning din motivasjon for studiet? Begrunn plasseringen Du må velge minst ett svaralternativ.

ए

Mye mindre motivert

Mindre motivert 
$\Gamma$

Det påvirket ikke min motivasjon

$\Gamma$

Mer motivert

$\Gamma$

Mye mer motivert

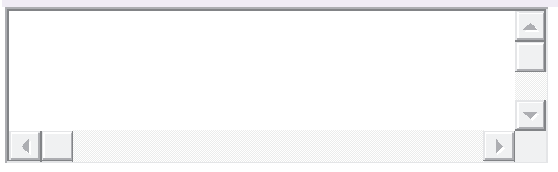

Hvordan påvirket omlegging til zoomundervisning ditt faglige utbytte?

Du må velge minst ett svaralternativ.

Г

mindre faglig utbytte med Zoom

$\Gamma$

ingen forskjell fra campusundervisning

$\Gamma$

større faglig utbytte med Zoom

Hvordan opplevde du kontakten med læreren?

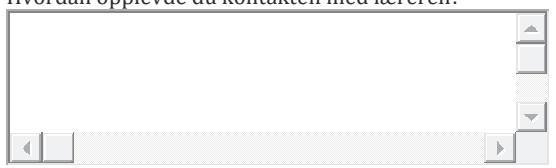

Hvordan opplevde du kontakten med de andre studentene?

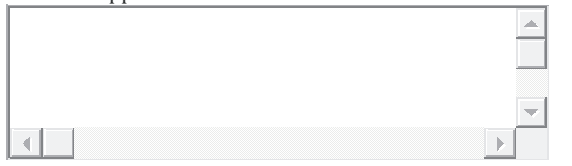

Hvordan opplevde du utviklingen fra første ukene til siste ukene med Zoomundervisning våren 2020?

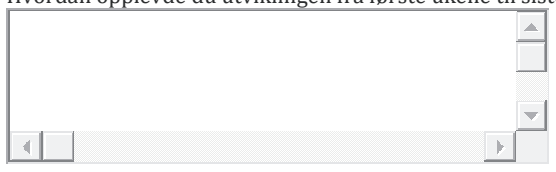

- Oppsummer dine erfaringer med Zoomundervisningen våren 2020 via 5 beskrivende ord

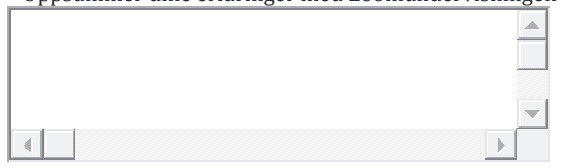




\section{ForSKNINGSPROSJEKT "UndERVISNING OG LÆRING GJENNOM ZOOM"}

Har du hatt ansvar for barn eller andre familiemedemmer i undervisningstiden?

Du må velge minst ett svaralternativ.

$\Gamma$

ja

nei

Har du hatt alt nødvending digitalt utstyr tilgjengelig?

Du må velge minst ett svaralternativ.

Г

ja

Г

nei

Er det noe mer du har lyst til å skrive?

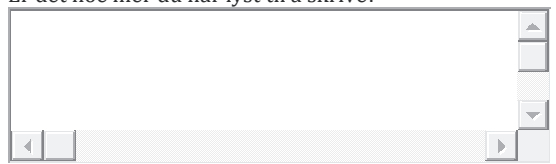

